\title{
PENYAKIT PERSPEKTIF AL-TIBB AL-NABAWY
}

\author{
Bahman \\ bahmanbakka1971@gmail.com \\ Dosen Tetap Universitas Muslim Indonesia
}

\begin{abstract}
Abstrak
Al-tibb al-Nabawi adalah pengobatan yang meliputi jasmani, sosial, mental dan spritual bagi individu, masyarakat dan kemanusiaan sepanjang masa, Al-Tibb alNabawi bukan sekedar pengobatan dalam pengertian sempit, sebagaimana pada istilah penyembuhan dalam kedokteran modern bahkan sering disebut sebagai pengobatan alternatif, al-tibb al-nabawi adalah petunjuk dari Nabi, sebagai Rasulullah saw. yang diberi ilmu dan akhlak, dan dengan wawasan psikologis yang lurus. Beliau mencapai pengetahuan tentang seluruh aspek kejiwaan manusia. Beliau juga sangat berpengalaman dalam memahami segala fenomena kehidupan desa dan kota. Atas semua itu, beliau menerima wahyu ilahi yang melampaui batas kemampuan manusia biasa.
\end{abstract}

Kata kunci: penyakit, attibb an nabawi

\section{Pendahuluan.}

Rasulullah saw adalah manusia yang paling sehat sepanjang sejarah manusia. Fakta sejarah menunjukkan bahwa beliau hanya dua kali sakit yaitu ketika beliau kena sihir dan ketika menjelang kematian beliau. Penyakit beliau hanya satu yaitu demam.

Penyakit dan kesehatan adalah dua sisi yang berbeda namun tidak dapat dipisahkan. Keduanya telah hadir dan berinteraksi dalam pasang surut sejarah kebudayaan manusia bersamaan dengan kehadiran manusia di muka bumi. Kesehatan senantiasa diharapkan kehadirannya namun penyakit selalu dihindari bahkan ia dimusuhi karena dianggap sebagai penyebab dan penghancur setiap citacita luhur manusia.

Pada dasarnya, penyakit hanyalah sebuah mata rantai siklus kehidupan yang mengitari perjalanan hidup manusia, sebab tidak seorang pun yang tidak pernah sakit sepanjang hidupnya. Sakit atau penyakit yang menimpa manusia adalah sebuah kemestian hidup yang harus diterima dengan lapang dada dan kesyukuran karena penyakit yang diderita manusia pada dasarnya akan mendatangkan kesehatan yang lebih besar melampaui kesehatan yang pernah dirasakan sebelumnya. Ia datang bukan untuk menghancurkan cita-cita manusia. Ia adalah agen rahmat Allah yang membawa ampunan dan pahala atas kesabaran seseorang yang ditimpa suatu penyakit. Sakit bukanlah sebuah momok yang menakutkan bagi manusia. Seorang yang sakit, agamanya akan semakin sehat karena akan melumpuhkan seseorang dari perbuatan dosa.

\section{Permasalahan}

Berdasarkan latar belakang di atas, maka permasalahan uang akan dibahas dalam tulisan ini adalah: 
Apa yang dimaksud dengan al-Tibb al-Nabawi?

Bagaimana bentuk-bentuk penyakit perspektif al-Tibb al-Nabawi?

\section{Pembahasan}

\subsection{Pengertian al-Tibb al-Nabawy}

Menurut Ahmad Rif'at al-Badrawi, Al-tibb al-Nabawi adalah pengobatan yang meliputi jasmani, sosial, mental dan spritual bagi individu, masyarakat dan kemanusiaan sepanjang masa, ${ }^{1}$. Al-Tibb al-Nabawi bukan sekedar pengobatan dalam pengertian sempit, sebagaimana pada istilah penyembuhan dalam kedokteran modern bahkan sering disebut sebagai pengobatan alternatif, al-tibb al-nabawi adalah petunjuk dari Nabi, sebagai Rasulullah saw. yang diberi ilmu dan akhlak, dan dengan wawasan psikologis yang lurus. Beliau mencapai pengetahuan tentang seluruh aspek kejiwaan manusia. Beliau juga sangat berpengalaman dalam memahami segala fenomena kehidupan desa dan kota. Atas semua itu, beliau menerima wahyu ilahi yang melampaui batas kemampuan manusia biasa.

Al-Tibb al-Nabawi adalah wahyu ilahi, bukan hasil fikiran manusia karena;1) Tidak ada catatan sejarah atau informasi apapun kalau Rasulullah saw pernah belajar tentang pengobatan; 2) Rasulullah saw. ummy, sehingga hal ini menafikan kalau beliau pernah belajar tentang hal apapun kepada orang lain; 3) Hikmah peristiwa penyerbukan kurma menunjukkan bahwa Rasulullah saw memang tidak pernah belajar kepada siapapun hingga tatacara mengawinkan buah kurma saja beliau tidak tahu; 4) al-tibb al-nabawi bersifat anatomik statistik sebagaimana hadis beliau tentang persendian yang jumlahnya 360. Hingga tahun 1997, jumlah persendian manusia masih disepakati sebanyak 340 namun enam tahun kemudian seorang dokter spesialis THT berkebangsaan Jerman menemukan bahwa satu telinga memiliki sepuluh persendian, dengan demikian jumlah persendian manusia persis seperti yang diungkapkan Rasulullah saw. Dokter ini pun masuk Islam. 5) Metode al-tibb al-nabawi belum pernah dikenal sebelumnya. Ini menunjukkan bahwa al-tibb al-nabawi bukan berasal dari bangsa tertentu. 6) Altibb al-nabawi tidak bertentangan dengan hasil penemuan modern. ${ }^{2}$

\subsection{Bentuk-Bentuk Penyakit.}

\section{Penyakit Jasmani}

Penyakit jasmani yang diamaksudkan di sini adalah penyakit-penyakit fisik yang umum dikenal oleh masyarakat seperti sakit mata, kanker dan seterusnya. Penyakit ini dinamakan penyakit medis atau sakit secara medis (medically ill). Wolisky membedakan 8 macam keadaan sehat yaitu : 1) Sehat secara normal, 2) Pesimis, 3) Sakit secara sosial, 4) Hipokondrik, ${ }^{3}$ 5) Sakit secara medis, 6) Martir,

${ }^{1}$ Lihat Abu 'Abdullah Muhammad bin Ahmad al-Z|ahabi, Al-Tib al-Nabawi (Cet. III; Beirut: Dar Ihya al-'Ulum, 1990), h.7.

${ }^{2}$ Abu al-Fida Muhammad 'Izzat Muhammad 'Arif, Asrar al-'Ilaj bi al-Hijamah wa alFasd (Qahirah: Dar al-Fadilah, 1424 H.), h. 7-12

${ }^{3}$ Suatu bentuk kegelisahan yang mengenai kesehatan seseorang dengan gejala yang beraneka ragam dan banyak yang tidak dapat ditemukan pada penyakit organik. Lihat: Difa Danis, Kamus Istilah Kedokteran, h. 327 
7) Optimis, 8) Sakit serius. ${ }^{4}$ Berdasarkan hasil penelitian Sarwono mengenai 8 macam keadaan sehat yang dikaitkan dengan definisi sehat menurut WHO yaitu fisik, mental dan sosial didapati bahwa sakit secara medis adalah sehat atau baik dalam pandangan psikologi dan sosial. ${ }^{5}$

Secara patologis, penyakit jasmani adalah seluruh penyakit yang hinggap pada tubuh manusia dalam struktur anatominya atau yang disebut patologi anatomi. ${ }^{6}$ Secara umum penyakit jasmani dikenal dalam kedokteran modern adalah penyakit mata, penyakit THT, penyakit gigi dan mulut, kebidanan dan kandungan, penyakit dalam dan penyakit kulit dan kelamin. ${ }^{7}$

Dalam al-Tibb al-Nabawi penyakit ini disebut dengan penyakit al-badani atau penyakit tubuh. ${ }^{8}$ Menurut Ibn al-Qayyim, cacat fisik termasuk penyakit jasmani. ${ }^{9}$

Penyakit organ tubuh adalah penyakit yang diakibatkan karena tidak berfungsinya sebagian anggota tubuh secara normal sehingga tidak dapat melaksanakan tugasnya secara sempurna atau tidak dapat menunaikan tugasnya sama sekali. Penyakit ini dapat juga diakibatkan oleh berbagai jenis mikroba yang masuk ke dalam tubuh manusia sehigga merusak sebagian anggota tubuhnya dan menyebabkan ia menderita sakit. Setiap penyakit organ tubuh yang seperti ini mempunyai gejala, riwayat, spesifikasi, dan komplikasi tertentu yang khas, sehingga dapat dibedakan dan didiagnosis dengan penyakit yang lainnya. ${ }^{10}$

Pengertian di atas menunjukkan bahwa penyakit jasmani adalah seluruh bentuk keluhan atau rasa sakit yang gejala dan manifestasinya tampak secara fisik pada diri seseorang karena adanya penyebab fisik secara langsung yang dapat diketahui berdasarkan gejala-gejalanya. Sebagian besar penyakit ini hanya dapat dikendalikan dengan meredakan gejalanya, seperti sakit kepala dengan obat flu yang meredakan gejala sakit kepala. Gejala penyakit untuk sementara waktu tidak terasa, namun penyakit semakin kuat bercokol dalam tubuh.

\section{Penyakit Mental}

Mental adalah salah satu dari tiga unsur yang menjadi tolak ukur sehat dalam WHO dan UU RI No. 23 Tahun 1993 tentang Kesehatan, selain fisik jasmani

${ }^{4}$ Hanum Marimbi, Sosiologi dan Antropologi Kesehatan, (Cet. I; Yogyakarta: Nuha Medika, 2009), h. 21.

${ }^{5}$ Solita Sarwono, Sosiologi Kesehatan, ( Cet. III; Yogyakarta: Gajah Mada University Press, 2004), h. 33

${ }^{6}$ Sutisna Himawan, Patologi, ( Jakarta: Fakultas Kedokteran Universitas Indonesia, 1988), h. 1 .

${ }^{7}$ Arief Mansyoer, (ed.) Kapita Selekta Kedokteran. Jilid I, edisi III (Cet. IV, Jakarta: Media Aesclapius FKUI, 2001), h. 47.

${ }^{8} \mathrm{Abu}$ 'Abdullah Muhammad bin Ahmad al-Zahabi, al-Tibb al-Nabawi, h. 7

${ }^{9}$ Ibn al-Qayyim al-Jauziyyah, al-Tibb al-Nabawi, (Cet. II, Beirut: Dar al-Fikr, t. th), h. 3

${ }^{10}$ Sya'ban Ahmad Salim, Mausu 'ah al- 'ilaj bi al-Qur'an wa al-Azkar, diterjemahkan oleh Irwan Raihan dengan judul Ensiklopedi Pengobatan Islam, (Cet. I, Solo: Pustaka Arafah, november 2012), h. 576 
dan sosial. Dalam ilmu kedokteran Barat, penyakit mental dinamai juga penyakit jiwa dan menjadi kajian ilmu kedokteran jiwa. Dalam al-Tibb al-Nabawi, mental bermakna al-nafsi yang merupakan salah satu dari empat unsur yang menjadi tolak ukur sehat selain jasmani atau al-badani>, al-'àqli> dan al-ru>hi,> sebagaimana yang telah dijelaskan. Dekadensi moral adalah sebuah penyakit mental disamping sebagai penyakit spritual. Penyakit mental ini, oleh Ibn al-Qayyim al-Jauziyyah, dinamai penyakit hati yang beragam gejalanya seperti takut, waswas, ragu dan sebagainya. ${ }^{11}$ Namun menurut hemat penulis ini adalah kelompok spritual karena beliau hanya membagi penyakit dalam dua bagian yaitu jasmani dan rohani.

Penyakit mental pada dasarnya adalah ragam gangguan yang memengaruhi jiwa seseorang yang tampak dalam tingkahlakunya. Penyebab penyakit ini awalnya berasal dari hal-hal yang fisik yang memengaruhi fungsi kognitif. Dalam ilmu kedokteran jiwa ada 6 (enam) jenis penyakit mental yaitu : 1) Gangguan mental organik, 2) Gangguan psikomotorik, 3) Gangguan neorotik, 4) Gangguan kepribadian dan retardasi mental, 5) Gangguan psikosomatik, 6) Gangguan psikiatri. $^{12}$

Menurut Hasan Langgulung, berdasarkan pandangan pemikir-pemikir Islam, penggerak dasar tingkahlaku manusia adalah ibadah dalam pengertiannya yang sangat luas. Ibadah bermakna pengembangan potensi-potensi yang lebih populer dengan sebutan asmaulhusna. Selama ia dikembangkan dengan wajar atau disertai dengan amanah, maka itulah tanda bahwa seseorang itu memiliki kesehatan mental yang wajar.

Beliau mencontohkan bahwa sebab kejatuhan Adam as dari surga, dalam hal ini umat manusia, adalah lupa; yaitu lupa kepada asmaulhusna yang telah diajarkan kepadanya setelah ia diciptakan dan lupa kepada janjinnya yaitu mengakui Tuhan sebagai satu-satunya Penguasa Yang Berhak Disembah. Inilah penyebab penyakit mental namun termanifestasi dalam berbagai bentuk seperti riya, nifaq, hasad, dengki dan seterusnya. ${ }^{13}$

Pendapat Hasan Langgulung di atas masih mencampurkan antara mental dan spritual. Fenomena kemunafikan seperti riya, nifaq, hasad dan dengki adalah penyakit spritual karena sifat-sifat ini tidak lahir dari adanya gangguan yang memengaruhi ruh seseorang yang tampak dari tingkahlakunya.

Penyakit ini pada hakekatnya mempunyai beragam penyakit dan jenisnya. Penderita dapat merasakan adanya penyakit ini namun dengan diagnosis dokter dan pemeriksaan melalui alat-alat modern seperti penyinaran dan beberapa analisis, kita dapat melihat dan mendapati pasien tersebut berada dalam kondisi normal, artinya tidak ditemukan penyakit fisik dalam tubuhnya. Penyakit ini terjadi karena pengaruh faktor luar dalam kehidupan seperti ketakutan, kebimbangan, sensitifitas

\footnotetext{
${ }^{11}$ Ibnu al-Qayyim al-Jauziyyah, al-Tibb al-Nabawi, h. 2

${ }^{12}$ Arief Mansyoer (ed. ). Kapita Selekta Kedokteran, h. 189-236

${ }^{13}$ Hasan Langgulung, Teori-Teori Kesihatan Mental, Cet. I, (Kajang, Selangor: Pustaka Huda, 1983), h. 253.
} 
perasaan, tidak mendapat kepuasaan seksual, stres dan sejenisnya. ${ }^{14}$ Termasuk juga adalah insomnia, gelisah, depresi, panik dan sidrom kelelahan. ${ }^{15}$

Penyakit-penyakit ini dapat juga berakibat pada munculnya penyakit fisik sebagai efek langsung dari ketidakstabilan emosi dan gangguan kejiwaan lainnya. Dalam menangani penyakit ini, tidak boleh tergesa-gesa karena seringkali sebuah penyakit mental melahirkan manifestasi ganda secara klinis dengan gejala yang sama.

3. Penyakit Sosial

Menurut sosiolog Talcot Parson, seseorang dianggap sehat manakala ia mempunyai kapasitas optimun untuk melaksanakan peran dan tugas yang dipelajarinya melalui proses sosialisasi, lepas dari soal apakah secara ilmu kesehatan ia sehat atau tidak. Karena itu, kesehatan sosiologis seseorang bersifat relatif karena tergantung pada peran yang dijalankan dalam masyarakat.

Pengertian ini dipahami bahwa penyakit sosial adalah penyakit atau salah satu bentuk dan keadaan yang mengganggu berfungsinya seseorang, sebagai anggota masyarakat dan merugikan kepentingan masyarakat. Itulah sebabnya, kematian dini dianggap sebagai penyakit karena merugikan masyarakat yang telah mengeluarkan biaya besar bagi kelahiran, pengasuhan dan sosialisasi anggota masyarakat. ${ }^{16}$

Teori lain tentang penyakit sosial adalah orang bersifat a sosial dan anti sosial. Sifat a sosial adalah orang yang tak dapat menyesuaikan diri dengan lingkungannya, sehingga sering kali melakukan tindakan-tindakan yang tidak sesuai dengan hukum-hukum yang berlaku dalam masyarakat. Orang seperti ini biasanya dibenci oleh masyarakat. Sifat anti sosial adalah sifat orang yang terangterang tindakannya bertentangan dengan hukum-hukum yang berlaku dalam masyarakat. Orang seperti ini sangat merugikan masyarakat. ${ }^{17}$

Pengertian di atas menunjukkan bahwa seseorang yang tidak peduli lingkungan secara umum dan hubungan dengan sesama manusia secara khusus, atau hablunminannas adalah orang yang sakit secara sosial.

Momon Sudarma melihat kesehatan sosial sebagai kesehatan pola sikap yang dikendalikan oleh pikiran. ${ }^{18}$ Pendapat ini sesuai dengan perfektif al-tibb alnabawi yang menyebut penyakit sosial dengan istilah al-'aqli karena dikendalikan oleh fikiran. Hal ini menunjukkan bahwa orang yang bertindak atau tindakan seseorang yang tidak rasional atau tidak sesuai dengan fikiran rasional adalah orang yang sakit secara sosial. Dalam pandangan lain, Penyakit sosial bukan hanya terjadi karena faktor sosial semata, tetapi terkait dengan ekonomi, sosial, budaya dan politik. Penyakit yang ditimbulkan oleh faktor-faktor tersebut dapat menjadi

${ }^{14}$ Sya'ban Ah\}mad Salim, Ensiklopedi Pengobatan Islam, h. 576.

${ }^{15 ، A b d u l ~ B a s i t\}}$ Muhammad al-Sayyid, al-Tibb al-Akhdar diterjemahkan oleh Nunuk Mas'ulah dengan judul Kitab Obat Hijau (Cet. I; Solo: Tinta Medina 2013), h. 61-70|||||

${ }^{16}$ Hanum Marimbi, Sosiologi dan Antropologi Kesehatan, h. 20-21

${ }^{17}$ Indan Entjang, Ilmu Kesehatan Masyarakat, (Cet. 12, Bandung: Citra Aditya Bakti, 1997), h. 20

${ }^{18}$ Momon Sudarma, Sosiologi untuk Kesehatan, (Jakarta: Salemba Medika, 2008), h. 20 
pemicu munculnya beragam bentuk penyakit lain selain penyakit sosial seperti penyakit jasmani dan mental. ${ }^{19}$ Dengan demikian, jelas bahwa meskipun sebuah penyaki tidak memiliki faktor tunggal sebagai penyebabnya namun ia memiliki faktor utama yang merupakan sumber dari setiap gejala yang ada.

4. Penyakit Spritual (al-Ruhi)

Penyakit spritual $^{20}$ adalah bagian yang tidak ditemukan dalam kedokteran Barat dan sekaligus pembeda antara kedokteran Barat/modern dengan al-Tibb alNabawi. Penyakit jenis ini bukan hanya terkait dengan hubungan kepada Tuhan dan pencarian hidup yang lebih bermakna, akan tetapi sikap-sikap kesombongan, rasa bangga, penipuan diri sendiri, kurang konsentrasi, perasaan gamang, suatu sikap yang tidak sopan dan sembrono dalam kehidupan, kebiasaan menyepelekan orang lain dan seterusnya, semuanya adalah penyakit spritual. ${ }^{21}$

Pengertian ini menunjukkan bahwa penyakit spritual adalah fenomenaefek samping kualitas individu pada tataran ruhani, baik yang berhubungan dengan manusia maupun dengan Sang Penciptaatau seseorang yang merasa kehilangan jati diri atau eksistensi diri atau semua kondisi yang berlawanan dengan asma al-husna.

Jenis penyakit ini kemudian lebih populer dengan istilah penyakit hati atau amrad al-qalb dan sekali lagi penyakit ini sama sekali tidak disinggung dalam ilmu kedokteran modern atau kedokteran Barat. Ibn al-Jauzy telah menjelaskan ragam penyakit spritual ini seperti hipokrit, dusta, hasad, dendam, marah dan semisalnya sebagai penyakit yang harus disembuhkan. ${ }^{22}$

Ketika sesuatu telah lepas dari dimensi spritualnya, dan yang ada hanyalah materialnya saja, dan ketika material ini mengendalikan kehidupan maka manusia seakan kehilangan arah. Krisis spritual bagi manusia menyebabkan terjadinya penyakit-penyakit hati yang menimbulkan berbagai kemudaratan, baik bagi individu sendiri maupun bagi orang lain. Krisis spritual juga akan menurunkan martabat manusia sejajar dengan martabat materi hewani, bahkan akan membawa manusia ke jurang kehancuran yang mengancam peradaban dan eksistensi manusia. ${ }^{23}$ Penyakit hati ini terdiri dari tiga jenis yaitu : 1) Penyakit kesamaran

${ }^{19}$ Kevin White, An Introduction to the Sosiology of Health, diterjemahkan oleh Ahmad Pediyani Saifuddin dengan judul Pengantar Sosiologi Kesehatan dan Penyakit, (Yogyakarta: Rajawali Press, 2011), h. 84-85

${ }^{20}$ Spritual adalah pengerahan segenap potensi rohaniyah dalam diri manusia yang senantiasa berorientasi keilahian, tunduk dan patuh pada ketentuan syar'I dalam melihat segala macam dan bentuk realitas, baik dalam dunia empiris maupun dalam dunia non-empiris sehingga nilai kesucian fitrah manusia tetap eksis dan citra kebenaran ilahi termanifestasikan dalam segala realitas. Lihat; Ruslan, Menyingkap Rahasia Spritualitas Ibn 'Arabi; Cet. I (Makassar: Pustaka alZ|ikra, Pebruari 2008), h. 235

${ }^{21} \mathrm{Abu}$ 'Abdullah Mu'inuddin Chisyti, The Book of Sufi Healing, diterjemahkan oleh Burhan Wirasubrata dengan judul Penyembuhan Cara Sufi (Cet. I, Jakarta: Lentera Basritama, 1999), h. 49

${ }^{22}$ Ibn al-Jauzi, al-Tibb al-Ruhani, (Cet. I, Cairo: Maktabah al-Saqafah al-Diniyyah 1986), h. 11

${ }^{23}$ Tamami, Psikologi Tasawuf,( Cet. I, Bandung: Pustaka Setia, 2001), h. 154 
(syubhat) dan ragu-ragu, 2) Penyakit syahwat dan kesesatan, 3) Penyakit lalai dan buta hati. ${ }^{24}$

Penulis memaknai penyakit spritual sebagai penyakit yang muncul karena fluktuasi tinggi rendahnya nilai-nilai spritual dalam diri seseorang sehingga lepas kendali dari nilai-nilai ilahiyah asmaulhusna Allah pada diri dan lingkungannya. Oleh karena itu, jika seseorang bersifat sombong misalnya, maka ia seharusnya diterapi dengan salah satu dari asmaulhusna yaitu al-mutakabbir, sehingga pada akhirnya ia menyadari bahwa sombong adalah salah satu bagian dari asmaulhusna yang hanya pantas disandang oleh Allah swt.

\section{Simpulan}

Al-Tibb al-Nabawi pada dasarnya adalah realitas cara sehat yang dilakoni Rasululullah saw dalam kehidupan sehari-hari ketika berinteraksi dengan diri sendiri, keluarga, sahabat dan masyarakat secara umum. Demikian juga tatacara beliau dalam beribadah kepada Allah swt.

Penyakit dalam presfektif al-tibb al-nabawi meliputi penyakit jasmani, penyakit sosial, penyakit mental dan penyakit spiritual. Ke empat penyakit ini saling bersinergi sehingga dalam upaya pengobatan, seorang pasien harus di diagnosa dari empat aspek di atas, karena tidak ada penyakit yang mempunyai faktor tunggal dalam penyebabnya.

\section{Daftar Pustaka}

Al- Zahabi, Abu 'Abdullah Muhammad bin Ahmad. Al-Tib al-Nabawi Cet. III; Beirut: Dar Ihya al-'Ulum, 1990

Muhammad 'Arif, Abu al-Fida Muhammad 'Izzat. Asrar al-'Ilaj bi alHijamah wa al-Fasd Qahirah: Dar al-Fadilah, $1424 \mathrm{H}$.

Difa Danis, Kamus Istilah Kedokteran, t.tp t.th.

Marimbi, Hanum. Sosiologi dan Antropologi Kesehatan, Cet. I; Yogyakarta: Nuha Medika, 2009

Sarwono, Solita. Sosiologi Kesehatan, Cet. III; Yogyakarta: Gajah Mada University Press, 2004

Himawan, Sutisna. Patologi, Jakarta: Fakultas Kedokteran Universitas Indonesia, 1988

Mansyoer, Arief. (ed.) Kapita Selekta Kedokteran. Jilid I, edisi III Cet. IV, Jakarta: Media Aesclapius FKUI, 2001

Al-Jauziyyah, Ibn al-Qayyim. al-Tibb al-Nabawi, Cet. II, Beirut: Dar alFikr, t. th.

Salim, Sya'ban Ahmad. Mausu'ah al-ilaj bi al-Qur'an wa al-Azkar, diterjemahkan oleh Irwan Raihan dengan judul Ensiklopedi Pengobatan Islam, Cet. I, Solo: Pustaka Arafah, november 2012

Langgulung, Hasan. Teori-Teori Kesihatan Mental, Cet. I, Kajang, Selangor: Pustaka Huda, 1983

\footnotetext{
${ }^{24}$ Sya'ban Ah\}mad Sa>lim, Ensiklopedi Pengobatan Islam, h. 575
} 
Muhammad al-Sayyid, 'Abdul Basit. Al-Tibb al-Akhdar diterjemahkan oleh Nunuk Mas'ulah dengan judul Kitab Obat Hijau . Cet. I; Solo: Tinta Medina 2013

Entjang, Indan. Ilmu Kesehatan Masyarakat, Cet. 12, Bandung: Citra Aditya Bakti, 1997

Sudarma, Momon. Sosiologi untuk Kesehatan, Jakarta: Salemba Medika, 2008.

Kevin White, An Introduction to the Sosiology of Health, diterjemahkan oleh Ahmad Pediyani Saifuddin dengan judul Pengantar Sosiologi Kesehatan dan Penyakit, Yogyakarta: Rajawali Press, 2011

Ruslan. Menyingkap Rahasia Spritualitas Ibn 'Arabi; Cet. I (Makassar: Pustaka al-Z|ikra, Pebruari 2008

Chisyti, Abu' Abdullah Mu'inuddin Chisyti. The Book of Sufi Healing, diterjemahkan oleh Burhan Wirasubrata dengan judul Penyembuhan Cara Sufi . Cet. I, Jakarta: Lentera Basritama, 1999

Ibn al-Jauzi. Al-Tibb al-Ruhani, Cet. I, Cairo: Maktabah al-Saqafah alDiniyyah 1986.

Tamami. Psikologi Tasawuf, Cet. I, Bandung: Pustaka Setia, 2001 